\title{
Social media and religion: Missiological perspective on the link between Facebook and the emergence of prophetic churches in southern Africa
}

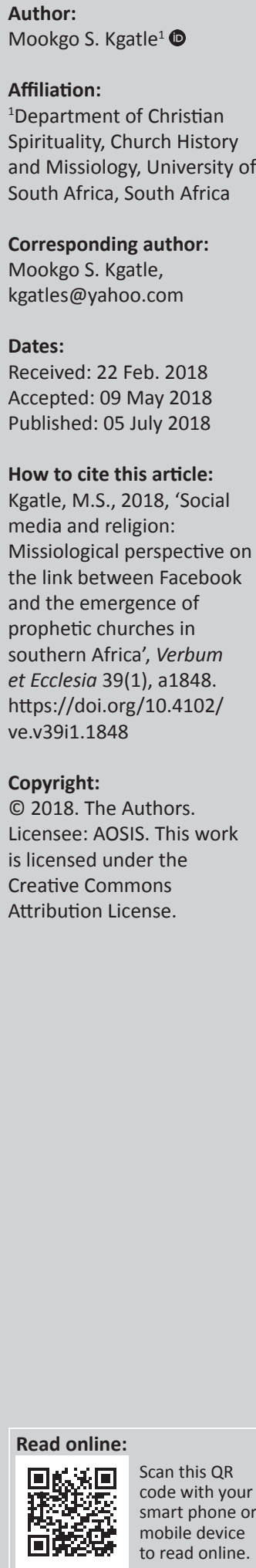

Recent works on social media and religion have paid particular attention to the role of social media in the development of religious values, improvement of social values and gratification of faith-based content by using various methodologies. A missiological perspective or approach to social media and religion will assist in exploring the role of Facebook in the emergence of prophetic churches. The background of prophetic churches is discussed here to demonstrate the growth of these churches and how such growth is linked to the use of Facebook. The shortcomings of the use of Facebook are highlighted and recommendations are made on how such shortcomings can be addressed in future.

Intradisciplinary and/or interdisciplinary implications: The article demonstrates the link between social media and religion on one hand and a link between Facebook and the emergence of prophetic churches on the other.

\section{Introduction}

One of the characteristics of prophetic churches, according to Faimau and Behrens (2016:68), is the use of media and, in particular, social media. The use of media among prophetic churches clearly assists to spread the Gospel to different people. Faimau and Behrens continue to say that prophetic churches have fully embraced the use of media technology to spread the Gospel faster and wider. This includes the use and appropriation of radio, television, the Internet, e-mail, mobile phones and various forms of print media. This article presents a missiological perspective on the use of Facebook and its impact on the emergence of prophetic churches in southern Africa. The shortcomings of the use of Facebook are highlighted and recommendations are made on how such shortcomings can be addressed in future.

\section{Religion and social media}

The link between social media and religion has attracted the interest of many scholars in the last decade. Lim and Putnam (2010:914), in their article 'Religion, social networks, and life satisfaction', state that social networks offer strong evidence for social and participatory mechanisms shaping religion's impact on life satisfaction. Although the rise of online social networking appears to represent a new challenge to religious individuals and institutions, Verschoor-Kirss (2012:1) opines that it is wrong to assume that the interaction between religion and technology is always adversarial. Generally, technology can enhance religious practices through the expansion and creation of religious communities.

Verschoor-Kirss (2012:9) continues to say that it would appear, therefore, that to unilaterally set up religion and technology as incompatible fails to take into account the complex ways in which both support and erode the other. Technology can be beneficial to religion when it enhances the communal aspects of religion, and detrimental to religion when it degrades these communal aspects. While there are certainly other aspects of religion that technology might influence, it would appear that community represents the most important one. Given the fact that online social networks generally appear to enhance notions of community, it is perhaps inevitable that religious organisations and individuals will turn to them in ever-increasing numbers. Whether this turn towards digital communities might inadvertently erode physical communities is unclear, though certainly possible (Verschoor-Kirss 2012:9).

Religion is also related to self-disclosures. Bobkowski and Pearce (2011), in their article 'Baring their souls in online profiles or not? Religious self-disclosure in social media', examined personal attributes associated with religious identification as well as the overall quantity of religious 
self-disclosures. Zviadadze (2014:164) suggests that increased religiosity is manifested not only in a traditional form of piety (church attendances, observance of rituals) but also in expression of religion in new media (clerics preaching on YouTube, a church bell as a ringtone on a mobile phone and a picture of a church as a desktop photo). Everton (2015:1) adds that social networks are crucial for the recruitment and retention of members of churches, the diffusion of religious ideas and practices, motivating individuals to volunteer in church work and become politically active, the health and well-being of people of faith.

The relationship between religion and social media has been discussed most recently. Faimau and Behrens (2016:66), for example, analysed the ways in which certain linguistic strategies and religious discourses used in Facebook posts, reviews and comments on a religion-based Facebook page create and shape the narratives of religious authority, religious identity and religious community. Brubaker and Haigh (2017:1) explored why Christians use Facebook for religious purposes and the need for engaging with religious content on Facebook. Coman and Coman (2017:129) show that in a post-secular society, the religious imagery is not only a 'canopy' inherited and kept because of convenience, but a cultural frame of the significant public sphere.

However, social networks do not offer only positive results; at times, it is a source of destruction. In fact, the use of social networks in religion has both advantages and disadvantages. Miller, Mundey and Hill (2013:227) mention sacred and secular influences on social networks' involvement and social behaviours, such as being in school and participating in organisations that are more non-religious.

It is pivotal therefore, instead of completely shutting down the use of social media, to outline what the advantages and disadvantages of such usage are in order to address them. In order to address the disadvantages of social media in religion, Al-Mosa (2015:126) highlighted the value aspect of social media by studying the problems that hinder the activation of the role of social networks regarding youth values. This article will reflect on these recent works on social media and religion by using a missiological approach or perspective. It will pay particular attention to the role of Facebook in the emergence of prophetic churches in southern Africa.

\section{Missiological perspective}

Missiology, according to Bosch (1991:9), as a branch of the discipline of Christian theology, is not a disinterested or neutral enterprise; rather it seeks to look at the world from the perspective of commitment to the Christian faith. Kritzinger (2013:5) adds that a missiological approach allows researchers to use insights from various academic disciplines (other theological subjects, anthropology, economics, communication science, linguistics, etc.) in pursuing their research. One feature of a missiological approach is therefore the way it combines approaches from different social sciences and integrates them into a coherent theological design.
Missiology is therefore by its very nature interdisciplinary. In this article, the interdisciplinary nature of missiology assists in linking social media with prophetic churches in southern Africa.

Kravtsev (2012:3) concurs that missiology is an interdisciplinary discipline which, through research, writing and teaching, furthers acquisition, development and transition of theologically informed, contextually grounded and ministry-oriented knowledge and understanding, with the goal of helping and correcting Christians, and Christian institutions, involved in Christian mission. Kravtsev goes further to say that missiology is an academic discipline aimed at understanding and explaining the specifics of the church's missionary calling in light of the Missio Dei. Being biblically based, it is historically informed, theologically balanced and grounded in particular cultural contexts with the ultimate purpose of directing the practice of the Christian mission in its specific settings.

Missiological method according to Kritzinger (2008:769) has two tasks: (1) Christians do not speak alone, but in interaction with people of another faith, thus nurturing mutuality; (2) not only doctrinal or 'universal' dimensions of the religious traditions are included but all the factors that shape religious identity and interreligious encounter, thus nurturing reflexivity and contextuality. In addition, the missiological approach wishes to achieve in response to the challenge of other religions an informed and respectful faith-to-faith encounter that happens 'uncushioned', face-to-face (Kritzinger 2008:770). The missiological perspective is explained by Botha (2009:2) as a kind of theological approach where some issues which people or the church or theology are grappling with in the 21st century become the lens through which theology is studied and taught. Therefore two-pronged issues: creating meaning and finding meaning.

Kritzinger (2013:5) continues to say that a missiological approach will express itself, among others, as the following:

- 'a sensitivity for the unique shape of mission practised by the community that is being researched

- a stance of commitment to the Christian faith (rather than rational scientism), matched by a fearless and self-critical scientific honesty

- an interest in the interrelations between God, Christian community and society, and not merely an interest in doctrinal descriptions of God, Christian community and the world

- an awareness that it is not only isolated aspects of people's lives and of the Christian faith that are missionary, but all of human life and society, coherently and holistically'.

Missiological perspective or approach in this context will help us to look at not only social media but also apply it to the context of prophetic churches in southern Africa. The methodology will assist us to link the emergence of prophetic churches with social media. In this article, a missiological perspective will be used to assess any loopholes in the use of social media and make recommendations. 


\section{The emergence of prophetic churches in southern Africa}

Prophetic churches were appropriated by Africans to establish a charismatic spirituality that would define African response to the Gospel: at once conservative, evangelical, with emphasis on the centrality of the Bible, interpreted without Western intellectual gymnastics, but with simplicity and immediacy. It is a Christianity with a vibrant liturgy with songs, music, dance and orality; under indigenous leadership; eschewing philosophical aridity; addressing problems raised within the interior of the primal worldview; negative about indigenous religions yet emphasising miracles, vision, dreams and healing (Kalu 2013:307). In these churches, there is an intense religious experience, a vision and a dream that may issue in prophetic speaking and actions, healing and community building (Kalu 2013:283).

Prophetic churches, in the words of Kustenbauder (2008:1), have not dominated the landscape in western Africa to the same extent as they have in eastern and southern Africa. The church in Africa, according to Kangwa (2016:5), is growing in leaps and bounds - unprecedented in the history of Christianity since its introduction on the continent in the 19th century. This growth and development, however, is taking place mainly in the new religious movements, particularly the prophetic churches, because of their emphasis on the prophetic ministry characterised by performance of healing miracles and predicting the future.

Prophetic churches, according to Shoko (2006:3), represent one of the most popular fastest growing movements in the African church. A quarter of the two billion Christians is said to be part of the movement. These churches are founded by a powerful charismatic leader, a prophet. The prophetic churches, according to Mpofu (2014:25), seek to determine lifestyle choices based on religious discourses as propagated by the founder leader. The spiritual life of the members is determined by the voice and message of the prophet; in addition, his or her voice and message is perceived by followers to be the voice and message of God.

The emergence of the prophetic churches in southern Africa came about because of many pastors breaking away from their traditional churches. Other pastors rose as founders of their own churches without being linked to a former traditional church. Under their own prophetic churches, these pastors have autonomy and freedom to practice religion at their own peril. In the words of Kalu (2013):

some operated as solo prophets whose charisma drew people to a new understanding of the power of the gospel; others formed new faith communities; still others operated as movements with inchoate leadership, but each affected the interior of Christianity just when colonial ideology colluded with missionary control and triumphalism. (p. 283)

Mpofu (2014:24) adds that there seems to be an identity reconstruction in the spirit of the charismatic religious movement as is clearly manifested through the manoeuvrings of Christians from the traditional churches to the newer prophetic churches associated with power and prosperity.

One of the appeals of the prophetic churches in southern Africa is its ability to respond to the existential and pragmatic needs faced by the modern urban congregations, including domestic and socioeconomic problems. Their emergence in most parts of Africa occurred under conditions of economic, political and social hardship, which were accompanied by economic reforms, low wages and quality of life, the absence of social services and the withdrawals of the welfare frontiers of the state (Chitando \& Biri 2016:75). The prophetic ministries attract people from different social classes, gender and age groups, including the top cadres in politics and the arts. The membership of these younger Pentecostal prophetic churches and/or ministries is not yet quite stable and there is constant movement within the sector as many seek miracles, healing and deliverance. In addition, most Christians who constitute the bulk of those patronising the services have been 'fished' from other Pentecostal denominations and other mainline and/or more established churches (Chitando \& Biri 2016:76).

The growth of these churches poses major missiological challenges for mainline churches, according to Mashau (2013:2), evangelical reformed denominations included. Whereas some evangelical reformed churches are experiencing a nosedive in terms of church growth, new Pentecostal churches are planted and growing in numbers on a daily basis in the same context. They have in some instances managed to pull substantial numbers from mainline churches, while other believers choose to embrace charismatic practices without leaving their churches. Mashau mentions factors like spontaneity and dynamism in worship, which includes contemporary music and dance as reasons that have managed to attract many young people from mainline churches to prophetic churches. What is missing in these reasons is the factor of social media that has also contributed to the emergence of prophetic churches in southern Africa.

\section{The role of Facebook}

Participation in Facebook ${ }^{1}$ is increasing dramatically around the globe. According to Miller et al. (2013):

the use of Facebook is especially high among younger adults: $86 \%$ of $18-29$-year-olds use Facebook, $31 \%$ of $18-22$-year-old Facebook users post status updates daily or more frequently compared with $3 \%$ of users over 49, 18-29-year-old Facebook users have substantially more online 'friends'. Usage is particularly high during university or college when a majority of students report daily use in order to communicate with friends they already know offline. Facebook use may also lead to increased social engagement: $82 \%$ of Facebook users belong to a voluntary group or organization compared with $75 \%$ of all adults and $56 \%$ of non-Internet users. (p. 228)

1This is the bigest social media network on the Internet, both in terms of total number fo users and name riactin (2 years managed tr 12 years managed to accumulate more than 1.59 billion monthly active users which automatically makes it one of the best mediums for connecting people from all ove the world with your business. It is estimated that more than 1 million small and medium-sized businesses use the platform to advertise their business. 
The latest local figures for the biggest social media platforms in South Africa for 2017, as part of the latest SA Social Media Landscape Report for 2018, show that Facebook remains the most popular platform in the country, with almost $30 \%$ of the population now connected. South Africa has about 16 million users of Facebook, 14 million of which access the site from mobile devices. Johannesburg has the most activity, with five million users. There is a misconception that younger people are leaving Facebook; however, a demographic breakdown of the local user data shows that it is just a case of the younger Facebook users getting older - simply put, they are not teenagers anymore (Businesstech 2017).

Facebook is playing a major role in the propagation of prophetic churches in southern Africa at least in four ways. Firstly, Facebook provides easy access to these churches and their spiritual services. This is because spiritual services at these churches can be watched on Facebook via smart phones that many people in southern Africa own. Prophetic churches' founders have a Facebook account where they can easily post the churches' services and even update their followers on the progress in their private lives. However, their following on Twitter ${ }^{2}$ is not as strong as that on Facebook. Twitter is more of a celebrity social media platform that even the most famous prophets would struggle to get a great following.

Secondly, Facebook serves as a great platform for the prophets to show their talents. Most Facebook users have the luxury of watching their favourite prophet on their smart phones. This further encourages the users to actually attend the services and be part of what is happening. The viewers who missed the daily services have an opportunity to watch them on Facebook. Users can watch the video numerous times as long as they have data on their cell phones. Users can also share videos with different people, including international viewers. Furthermore, users have an option to leave comments as to why they like or do not like a specific video.

Thirdly, Facebook serves as an advertising platform, whereby the upcoming events will be advertised on the church Facebook page. Hence, the attendance at many events of the prophetic churches is excellent. It is because Facebook serves as free medium for advertisement for these churches. While the content of the Facebook postings on the pages of these prophetic churches vary, the postings, according to Faimau and Berhens (2016:69), generally include biblical verses, wellformulated religious messages, words from the prophet or prophetess, blogging of religious services, postings of pictures or videos, testimonies and postings of religious products.

Lastly, Facebook offers the advantage of a space where interactions between members can take place. Faimau and Berhens continue to say that Facebook posts and posted

2.Twitter has more than 320 million active monthly users who make use of the 140 -character limit to pass on information. Businesses can use Twitter to interat with prospective clients, answer questions, release latest news and at the sam with prospective clients, answer questions, release latest news and at the same time use the targeted ads with specific audiences. Twitter was founded on $21 \mathrm{March}$ 2006 and has its headquarters in San Francisco, California. comments therefore create spaces for the discovery of a 'shared identity' among Facebook users. Facebook users who commented on specific testimonial narratives posted on the Facebook page immediately aligned themselves with the autobiographical narrative of the one who shared the testimony. For a religious Facebook user, the religious identity of the person should be provided (Faimau \& Berhens 2016:82).

Facebook use by individuals and organisations and its popularity make it imperative for the church to also take advantage of this phenomenon to spread the Gospel of Jesus Christ. Facebook analogically serves as a stethoscope, magnifying one's ability to listen to your congregation and community, and a megaphone, magnifying the individual's ability to proclaim God's Word to your community. The primary purpose of using social media is to establish and maintain relationships; to connect with and stay connected with members of the congregation (White, Tella \& Ampofo 2016:3).

According to Coman and Coman (2017:131), interactions between and among believers, and between believers and non-believers can be easily observed in their spontaneous forms and unmediated by other institutions. Everton (2015:21) adds that Facebook is crucial for the diffusion of religious ideas and practices, as well as motivating individuals to volunteer and become civically engaged. Faith community networks also vary in terms of their composition, reflecting not only their tension with the surrounding society but also their socioeconomic class. Facebook also appears to play a key role in the health and subjective well-being of people of faith because believers can share scriptures on the platform. Facebook is considered a very important means to get societies closer to each other. It is useful in developing some values that the youth can use to behave accordingly with others (Al-Mosa 2015:126).

Facebook allows users to create a simple, digital extension of their personal relationships and friendships. Indeed, Facebook describes itself as (Mashable 2010):

a social utility that helps people communicate more efficiently with their friends, family and co-workers. The company develops technologies that facilitate the sharing of information through the social graph, the digital mapping of people's realworld social connections. (p. 1)

From simple beginnings, Facebook has grown into the largest online social network and is a daily staple of high school and college students as well as a growing number of older adults. Religious groups have confronted this new technology in two main ways: creating their own versions of social network sites that are religion-centric and somewhat exclusive, and using the functions of larger social networks such as Facebook to their advantage (Verschoor-Kirss 2012:5).

Considering the rapid adoption of Facebook, it is not surprising that individuals, religious leaders and congregations have used these networks to bolster religious participation. The use of social media for religious communication has brought 
growth in many religious groups and individual worshippers (Brubaker \& Haigh 2017:1). The current findings suggest Facebook is an expressive medium where users can both give and receive spiritual support, expressing beliefs and informing others about religious practices and perspectives while at the same time receiving spiritual guidance, religious resources and entertainment for themselves. Facebook provides an outlet through which religious needs and desires are expressed and fulfilled online (Brubaker \& Haigh 2017:7).

\section{Shortcomings of Facebook}

The first shortcoming is the authenticity of Facebook users. So many Facebook users do not use their real names but pseudonyms; for example, if somebody's real name is Tumelo Makgate, the person might prefer to be called Tumza McGate on Facebook. As a result, it cannot be verified that the more than two million likes that one prophet has on Facebook are actually real likes or even more than two million followers are real followers.

This brings us to the second shortcoming, namely the multiplicity of Facebook usage. Most people in Facebook have multiple accounts. This is easy because all that one needs to have a Facebook account is an e-mail address. Equally, one person can have many different e-mail accounts.

The third shortcoming is the publication of false information on Facebook. The prophetic churches in southern Africa, according to Mochechane (2016:14), has been criticised for staged miracles, fake prophecies, etc. Hameno (2014:1) adds that the prophetic activities that are reported on Facebook range from the bizarre to the outrageous and sometimes immoral or even criminal. Hameno continues to say that bizarre claims of being able to make a person pregnant and deliver a baby in three days or being able to produce miracle money which appears from nowhere and is found in one's pocket or bank account are the order of the day. Outrageous and perhaps irresponsible claims abound.

The fourth shortcoming is the duplicity of information. There is a sense of exaggeration on Facebook, whereby one testimony can be manipulated as if it is a great testimony or many testimonies. Other issues on Facebook are more pronounced than what has actually happened in reality. These factors can lead to social disruption and disadvantages in Pentecostal prophetic churches. It can cause non-believers to dislike prophetic churches, especially non-believers who are middle class with a certain level of education. When things do not make sense to them, they cannot believe in them.

The final shortcoming is negative publicity. As much as Facebook can help the church to promote her work among believers and non-believers, there is a disadvantage when it comes to negative publicity. The same users who used to promote the pastor will be the ones to demote him when they face challenges in life. Coman and Coman (2017:137) say that several negative comments cause the pastor to be perceived negatively and the integrity of Christian church in general is compromised. The commentators seem to point out an awareness that in modernity the Church and religion was confronted with a prestige loss and therefore any inadequate behaviour of a religious leader worsens the situation.

\section{Recommendations}

Prophetic churches need to authenticate their Facebook users to try to deal with users who use pseudonyms. This will also prevent users from duplicating their accounts because they will be authentic users. These churches need to post real miracles to earn credibility, especially with the middle class and the rich people. They need to avoid at all cost exaggerating testimonies or advertising staged miracles on Facebook. Prophetic churches can benefit more from Facebook and other social networks if they approach Facebook from an ethical point of view. The church has an ability to attract more non-church-goers or non-believers by offering the real message of the Gospel instead of grandstanding on Facebook and other media.

With the above concerns on the shortcomings of social media, White et al. (2016:6) suggest that it is very important that Christians approach social media in a discerning manner. It is therefore essential to understand the impact our status, photos, comments or blog posts may have now and in future. We should also bear in mind the ramifications of any statement made on social media as everything written is permanent and viewable by everyone. Furthermore, while maintaining relationships is important and healthy, addiction is not. Facebook is a good medium for advertising but not so effective in creating and maintaining relationships. Limiting the amount of time we devote to these social networking sites is both healthy and wise. Most of our time should be devoted to prayer and meditation.

\section{Conclusion}

This article has been a study on a missiological approach to the role of Facebook in the emergence of the prophetic churches in southern Africa. The article discussed the emergence of the prophetic churches and demonstrated their growth. The shortcomings of Facebook are highlighted in the article. It is recommended here that the prophetic churches should authenticate their own followers on Facebook. Prophetic churches must post real testimonies to avoid falsified information and negative publicity.

\section{Acknowledgements}

The author is thankful to the Department of Christian Spirituality, Church History and Missiology for its contributions to the study.

\section{Competing interests}

The author declares that he has no financial or personal relationships that may have inappropriately influenced him in writing this article. 


\section{References}

Al-Mosa, N.A., 2015, 'Role of social networks in developing religious and social values of the students of the World Islamic Sciences \& Education University', International Education Studies 8(9), 126-137. https://doi.org/10.5539/ies. v8n9p126

Bobkowski, P.S. \& Pearce, L.D., 2011, 'Baring their souls in online profiles or not? Religious self-disclosure in social media', Journal for the Scientific Study of Religion 50(4), 744-762. https://doi.org/10.1111/j.1468-5906.2011.01597.x

Bosch, D.J., 1991, Transforming mission: Paradigm shifts in theology of mission, vol. 16, Orbis Books, New York.

Botha, N., 2009, 'John Calvin in missiological perspective: On church unity and social justice', Studia Historiae Ecclesiasticae 35(2), 1-16.

Brubaker, P.J. \& Haigh, M.M., 2017, 'The religious Facebook experience: Uses and gratifications of faith-based content', Social Media + Society 3(2), 1-11. https:// doi.org/10.1177/2056305117703723

Businesstech, 2017, How many people use Facebook, Twitter and Instagram in South Africa, viewed 18 September 2017, from http://www.businesstech.co.za

Chitando, E. \& Biri, K., 2016, 'Walter Magaya's Prophetic Healing and Deliverance (PHD) Ministries and Pentecostalism in Zimbabwe: A preliminary study with particular reference to ecumenism', Studia Historiae Ecclesiasticae 42(2), 72-85. https://doi.org/10.17159/2412-4265/2016/829

Coman, I.A. \& Coman, M., 2017, 'Religion, popular culture and social media: The construction of a religious leader image on Facebook', ESSACHESS - Journal for Communication Studies 10(20), 129-143.

Everton, S.F., 2015, 'Networks and religion: Ties that bind, loose, build up, and tear down', Journal of Social Structure 16(1), 1-34.

Faimau, G. \& Behrens, C., 2016, 'Facebooking religion and the technologization of the religious discourse: A case study of a Botswana-based Prophetic Church', Online Heidelberg Journal of Religions on the Internet 11(1), 66-92.

Hameno, N., 2014, The political and social impact of prophetic churches in Zimbabwe, viewed 04 October 2014, from http://www.kas.de/Zimbabwe

Kalu, O., 2013, African Christianity: An African story, Department of Church History, University of Pretoria, Pretoria.

Kangwa, J., 2016, 'The role of the theology of retribution in the growth of PentecostalCharismatic churches in Africa', Verbum et Ecclesia 37(1), a1542. https://doi. org/10.4102/ve.v37i1.1542
Kravtsev, A., 2012, 'What is missiology?', A paper submitted for partial fulfilment of the requirements for the course ME 9050 Prolegomena: Missiology as a Discipline at Trinity Evangelical Divinity School, Deerfield, IL.

Kritzinger, J.N.J., 2008, 'Faith to faith - Missiology as encounterology', Verbum et Ecclesia 29(3), 764-790. https://doi.org/10.4102/ve.v29i3.31

Kritzinger, J.N.J., 2013, Tutorial letter for the research proposal module in the structured Master of Theology in Missiology, University of South Africa, Pretoria.

Kustenbauder, M., 2008, 'Prophetic movements: Western Africa', in J. Middleton \& J.C. Miller (eds.), New encyclopedia of Africa, pp. 273-279, 4th edn., Thomson/Gale, Detroit, MI.

Lim, C. \& Putnam, R.D., 2010, 'Religion, social networks, and life satisfaction', American Sociological Review 75(6), 914-933. https://doi.org/10.1177/0003122410386686

Mashable, 2010, Facebook's insignia and the company's ultimate mission, viewed 04 June 2010, from https://mashable.com/2010/06/04/facebook-insignia

Mashau, T.D., 2013, 'Ministering effectively in the context of Pentecostalism in Africa: A reformed missional reflection', In die Skriflig/In Luce Verbi 47(1), Art. \#84, 8 pages. https://doi.org/10.4102/ids.v47i1.84

Miller, B.J., Mundey, P. \& Hill, J.P., 2013, 'Faith in the age of Facebook: Exploring the links between religion and social network site membership and use', Sociology of Religion 74(2), 227-253. https://doi.org/10.1093/socrel/srs073

Mochechane, S., 2016, 'Dealing with Fear and Anxiety in Pentecostalism: The BushiriPhenomenon in Pretoria', A CHSSA paper presented at the Third Conference of Academic Societies in the Fields of Religion and Theology, pp. 1-16, University of Pretoria, 11-15 July, 2016, Pretoria.

Mpofu, S., 2014, 'The "Third Wave" religious right movement and the growth of Zimbabwean Christianity: Faith or economic response?', Doctoral dissertation, University of Pretoria.

Shoko, T., 2006, 'Independent church healing: The case of St Elijah cum Enlightenment School of the Holy Spirit in Zimbabwe', Studia Historiae Ecclesiasticae 33(3), 129-153.

Verschoor-Kirss, A., 2012, 'Even Satan gets likes on Facebook: The dynamic interplay of religion and technology in online social networks', Journal of Religion \& Society $14(1), 1-12$

White, D.P., Tella, F. \& Ampofo, M.D., 2016, 'A missional study of the use of social media (Facebook) by some Ghanaian Pentecostal Pastors', Koers 81(2), 1-8. https://doi.org/10.19108/KOERS.81.2.2250

Zviadadze, S., 2014, "I "like" my Patriarch. Religion on Facebook. New forms of religiosity in Contemporary Georgia', Online - Heidelberg Journal of Religions on the Internet 6(1), 164-194. 